\title{
Involvement of the $C D C 25$ gene product in the signal transmission pathway of the glucose-induced RAS-mediated cAMP signal in the yeast Saccharomyces cerevisiae
}

\author{
Linda Van Aelst, ${ }^{1}$ ARnold W. H. Jans ${ }^{2}$ and Johan M. TheVelein ${ }^{1 *}$ \\ ${ }^{1}$ Laboratorium voor Cellulaire Biochemie, Katholieke Universiteit te Leuven, Kardinaal Mercierlaan 92, B-3001 Leuven- \\ Heverlee, Flanders, Belgium \\ ${ }^{2}$ Max-Planck-Institut für Systemphysiologie, Rheinlanddamm 201, D-4600 Dortmund 1, FRG
}

(Received 18 June 1990; revised 28 August 1990; accepted 4 October 1990)

\begin{abstract}
Addition of glucose or related fermentable sugars to derepressed cells of the yeast Saccharomyces cerevisiae triggers a RAS-protein-mediated cAMP signal, which induces a protein phosphorylation cascade. Yeast strains without a functional $C D C 25$ gene were deficient in basal cAMP synthesis and in the glucose-induced cAMP signal. Addition of dinitrophenol, which in wild-type strains strongly stimulates in vivo cAMP synthesis by lowering intracellular pH, did not enhance the cAMP level. $c d c 25$ disruption mutants, in which the basal cAMP level was restored by the $R A S 2^{\text {val19 }}$ oncogene or by disruption of the gene (PDE2) coding for the high-affinity phosphodiesterase, were still deficient in the glucose- and acidification-induced cAMP responses. These results indicate that the $C D C 25$ gene product is required not only for basal cAMP synthesis in yeast but also for specific activation of cAMP synthesis by the signal transmission pathway leading from glucose to adenyl cyclase. They also show that intracellular acidification stimulates the pathway at or upstream of the CDC25 protein. When shifted to the restrictive temperature, cells with the temperature sensitive $c d c 25-5$ mutation lost their cAMP content within a few minutes. After prolonged incubation at the restrictive temperature, cells with this mutation, and also those with the temperature sensitive $c d c 25-1$ mutation, arrested at the 'start' point (in $\mathrm{G}_{1}$ ) of the cell cycle, and subsequently accumulated in the resting state $G_{0}$. In contrast with $c d c 25-5$ cells, however, the cAMP level did not decrease and normal glucose- and acidification-induced cAMP responses were observed when $c d c 25-1$ cells were shifted to the restrictive temperature. These results show that, in the original genetic background at least, growth arrest of cdc25-1-bearing cells at the restrictive temperature is not due to cAMP deficiency. Previous experiments have provided evidence for the presence of a glucose-repressible protein in the signalling pathway. Exponential-phase glucose-grown cells of a strain with overexpression of $C D C 25$ unexpectedly showed a glucose-induced cAMP signal. Control experiments, however, indicated that overexpression of $C D C 25$ caused a defect in glucose repression. Introduction of the cat 1 derepression mutation in the strain with overexpression of $C D C 25$ restored glucose repression and abolished the glucose-induced cAMP signal, indicating that the CDC25 protein is not the glucose-repressible component of the signalling pathway.
\end{abstract}

\section{Introduction}

When glucose or related fermentable carbon sources are added to derepressed cells, stationary-phase cells or to ascospores of the yeast Saccharomyces cerevisiae, a cAMP signal is induced which triggers a protein phosphorylation cascade, similar to the hormone-induced cascades in mammalian cells (for a recent review, see Thevelein, 1988). The mechanism by which glucose triggers the cAMP signal is not well understood. It has been shown that transient plasma membrane depolarization, transient intracellular acidification and increased energy supply are not triggers for the cAMP signal. Recent studies have provided evidence for the existence of a specific signal transmission pathway. The RAS proteins, which in yeast probably act in a way similar to the $G_{s}$ proteins of mammalian adenyl cyclase (Defeo-Jones et al., 1983, 1985; Dhar et al., 1984; Kataoka et al., 1984, 1985; Toda et al., 1985), have been implicated as signal transmitters in the pathway (Mbonyi et al., 1988). The requirement of glucose metabolism for induction of the cAMP signal is very limited. Transport of glucose alone is unable to induce the cAMP signal, but the presence of a functional sugar kinase (hexokinase 1 , hexokinase 2 or 
glucokinase) in the only other requirement. Whether the kinase is needed for phosphorylation of the sugar, or for another reason, is not yet clear (Beullens et al., 1988). Experiments with a mutant lacking the $S N F 3$ gene, which encodes the high-affinity glucose carrier, have shown that this carrier is not required for induction of the cAMP signal (Mbonyi \& Thevelein, 1988). This implies that the putative mechanism of transport-associated phosphorylation of sugar is not involved in induction of the cAMP signal (Beullens \& Thevelein, 1990).

The yeast $\mathrm{CDC} 25$ protein forms a functional complex with the RAS-adenyl cyclase system (Broek et al., 1987; Camonis et al., 1986; Daniel, 1986; Daniel et al., 1987; Martegani et al., 1986a; Robinson et al., 1987). In the absence of CDC 25 or RAS proteins, the basal cAMP level in yeast cells is extremely low (Broek et al., 1987). To differentiate between the alternatives that the CDC25 gene product is merely needed to sustain basal cAMP synthesis and that it acts as a component of the signal transmission pathway leading from glucose to adenyl cyclase, we have investigated glucose-induced cAMP signalling in $c d c 25$ mutants in which the capacity for basal cAMP synthesis was restored by the presence of the $R A S 2^{\text {val19 }}$ oncogene in the genome or on a plasmid. These strains always contained at least one additional wild-type $R A S$ gene which allows for transmission of the glucose-induced cAMP signal, even in the presence of the $R A S 2^{\text {val19 }}$ oncogene product (Mbonyi et al., 1988). These experiments showed that the CDC25 protein functions as a component of the signalling pathway. Recent experiments by Munder \& Küntzel (1989) also pointed to involvement of CDC25 in glucose-induced cAMP signalling.

In vivo cAMP synthesis in yeast is strongly stimulated by intracellular acidification (Caspani et al., 1985; Purwin et al., 1986; Thevelein et al., 1987a). Previous evidence indicated that lowered intracellular $\mathrm{pH}$ does not act directly on adenyl cyclase, but rather on the RAS proteins or on other controlling elements situated upstream in the activation pathway of the enzyme (Mbonyi et al., 1988). In this paper, we have investigated whether a functional $\mathrm{CDC} 25$ protein is required for the acidification-induced increase in cAMP. Experiments with glucose-repressed and derepressed wild-type cells, and with repression and derepression mutants, have shown that fermentable sugar is able to induce a cAMP signal only in derepressed cells and not in glucoserepressed cells. This has led to the hypothesis that the signalling pathway contains a glucose-repressible protein (Beullens et al., 1988; Argüelles et al., 1990; Mbonyi et al., 1990). We have made use of strains with overexpression of $\mathrm{CDC} 25$ to determine whether $\mathrm{CDC} 25$ is the putative glucose-repressible protein of the pathway.

Temperature-sensitive $c d c 25$ mutants behave as cell cycle mutants. They arrest at the restrictive temperature at a point called 'start' in the $G_{1}$ phase of the cell cycle and subsequently accumulate as round unbudded cells in the resting state $G_{0}$. The same is true for temperaturesensitive mutants in $C D C 35$, the gene for adenyl cyclase (Boutelet et al., 1985; Casperson et al., 1985; Kataoka et al., 1985). Whereas $c d c 25$ disruption mutants clearly have very low cAMP levels (Broek et al., 1987), conflicting results have been published for cAMP levels in cells bearing temperature-sensitive alleles of $C D C 25$, incubated at restrictive temperatures. Experiments with cells carrying the $c d c 25-5$ allele showed a rapid drop of the cAMP level upon shift to the restrictive temperature (Camonis et al., 1986). On the other hand, in cells of the cdc25-1 mutant the cAMP level did not significantly change (Martegani et al., 1986b; Portillo \& Mazon, 1986). These results were obtained by different authors using different methods for cAMP extraction and determination. Because of the proposed importance of the CDC25/RAS/adenyl cyclase pathway for progression over the 'start' point of the yeast cell cycle we have reinvestigated the possible difference between $c d c 25-1$ and $c d c 25-5$ and found it, at least in the original genetic background of the two strains, to be true.

\section{Methods}

Yeast strains. Saccharomyces cerevisiae strains used in this study are shown in Table 1. Plasmid pL25S-P [a derivative of YRP7 (TRPl) which contains the $C D C 25$ gene] was kindly provided by $M$. Jacquet (Orsay, France) and introduced into strains SP1, JT2000 and JT2010 to give, respectively, strains JT4101, JT4200 and JT4300 (Table 1). Plasmid YEp $\left(R A S 2^{\text {val19 }}+\right.$ LEU2) was isolated from strain TT1A-5, kindly provided by $M$. Wigler (Cold Spring Harbor) and introduced into strain SP1 to give strain JT4100. Strain JT1821 was obtained from a cross between strain TK 161-R2V and strain TT1 A-2 after selection of the diploid for plasmid ( $L E U 2)$ loss. Heat shock sensitivity, basal trehalase activity and trehalose levels in the newly constructed strains were consistent with previous results reported in the literature (Broek $e t$ al., 1987). Strain JT5011 (cdc25- pde2) was obtained from a cross between strains JT5001 (pde2) and T139-5A-6A (cdc25::HIS3) ${ }^{\text {w }} /$ YEp $\left(R A S 2^{\text {val19) }}\right)$ after selection of the diploid for plasmid (LEU2) loss. Strains JT2000 (catl) and JT2010 (CATI) were obtained from a cross between HRX.42-13C (catl), kindly provided by K.-D. Entian (Tübingen, FRG) and DBY747 (wild-type).

Culture and heat shock conditions. The cells were grown to a density of about $8 \mathrm{mg}$ (wet weight) $\mathrm{ml}^{-1}$ in a gyrotatory incubator ( 200 r.p.m.) at $22^{\circ} \mathrm{C}$ (temperature-sensitive strains), $37^{\circ} \mathrm{C}$ (temperature-sensitive strains containing plasmids) or $30^{\circ} \mathrm{C}$ (all other strains). Composition of the growth media was as follows. YPG: $3 \%(\mathrm{v} / \mathrm{v})$ glycerol, $2 \%(\mathrm{w} / \mathrm{v})$ peptone (Merck 7224$)$ and $1 \%(\mathrm{w} / \mathrm{v})$ yeast extract. YPD: $2 \%(\mathrm{w} / \mathrm{v})$ glucose, $2 \%(w / v)$ peptone and $1 \%(w / v)$ yeast extract. YPGal: $2 \%$ $(\mathrm{w} / \mathrm{v})$ galactose, $2 \%(\mathrm{w} / \mathrm{v})$ peptone and $1 \%(\mathrm{w} / \mathrm{v})$ yeast extract. Strains in which the plasmid is not required for growth on rich media were cultured on minimal media (Sherman et al., 1985) lacking the nutrient specified by the selectable marker on the plasmid.

Heat shock was performed by replica-plating cell patches to plates (YPD or minimal glucose medium without leucine) that had been preheated at $55^{\circ} \mathrm{C}$. The plates were incubated for $30,60,90$ or $120 \mathrm{~min}$ 
Table 1. Saccharomyces cerevisiae strains used in this study

\begin{tabular}{|c|c|c|}
\hline Strain & Genotype & Source (and reference) \\
\hline A364A & MATa adel ade 2 ural his7 lys 2 tyrl gall & Yeast Genetic Stock Center \\
\hline SP1 & MATa his3 leu 2 ura 3 trpl ade8 canl & M. Wigler (Toda et al., 1985) \\
\hline TK161-R2V & MATa his3 leu 2 ura3 trpl ade8 canl RAS2 $2^{\text {val19 }}$ & M. Wigler (Toda et al., 1985) \\
\hline T139-5A-6A ${ }^{*} / \mathrm{YEp}(C D C 25)$ & $\begin{array}{l}\text { MAT } \alpha \text { his3 leu2 ura3 trpl ade8 } \\
\text { cdc25:: HIS3 } \mathrm{pCDC} 25 \text { (LEU2) }\end{array}$ & M. Wigler (Broek et al., 1987) \\
\hline $\mathrm{T} 139-5 \mathrm{~A}-6 \mathrm{~A} * / \mathrm{pCl}^{25}-8$ & $\begin{array}{l}\text { MAT } \alpha \text { his3 leu2 ura3 trpl ade8 } \\
\text { cdc25:: HIS3 } \mathrm{pTPK1} \text { (LEU2) }\end{array}$ & M. Wigler (Broek et al., 1987) \\
\hline $\mathrm{T} 139-5 \mathrm{~A}-6 \mathrm{~A}{ }^{\mathrm{w}} / \mathrm{YEp}\left(R A S 2^{\text {val199}}\right)$ & $\begin{array}{l}\text { MAT } \alpha \text { his3 leu2 ura3 trpl ade8 } \\
\text { cdc25::HIS3 pRAS2 val19 (LEU2) }\end{array}$ & M. Wigler (Broek et al., 1987) \\
\hline JT1821 & MAT $\alpha$ his 3 leu2 ura3 trpl ade8 canl cdc25::HIS3 RAS2 $2^{\text {val19 }}$ & This work \\
\hline JT4100 & MATa his3 leu2 ura3 trpl ade8 can1 $\mathrm{p} R A S 2^{\mathrm{val} 19}$ (LEU2) & This work \\
\hline JT5001* & MATa his 3 leu 2 ura 3 trpl ade8 pde $2:: U R A 3$ & This work \\
\hline JT5011 & 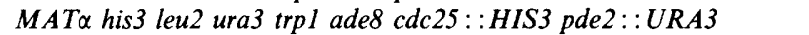 & This work \\
\hline t.s. 321 & MATa cdsc25-1 adel ade2 ural his7 lys2 tyrl gall & Yeast Genetic Stock Center \\
\hline OL86 & MAT $\alpha$ cdc25-5 ade2 leu 2 trpl & M. Jacquet (Camonis et al., 1986) \\
\hline OL97-1-11B pL25 & $\begin{array}{l}\text { MATa cdc25-5 leu2 ura3 his } \\
\mathrm{pH} 61(C D C 25+\text { URA3) }\end{array}$ & M. Jacquet (Camonis et al., 1986) \\
\hline DBY747 & MATa his3- $\Delta 1$ leu2-3 leu2-112 ura3-52 trpl-289 & Yeast Genetic Stock Center \\
\hline HRX.42-13C & 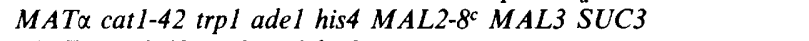 & K.-D. Entian \\
\hline JT2000 & MATa cat $1-42$ ura3 trpl his 3 & This work \\
\hline JT2010 & $M A T \alpha C A T 1$ ura3 trpl & This work \\
\hline JT4101 & MATa his3 leu2 ura3 trpl ade8 canl pL25S-P $(C D C 25+T R P I)$ & This work \\
\hline JT4200 & MATa cat $1-42$ ura 3 trpl his 3 pL25S-P $(C D C 25+T R P I)$ & This work \\
\hline JT4300 & $M A T \alpha C A T 1$ ura3 trp1 pL25S-P $(C D C 25+T R P I)$ & This work \\
\hline
\end{tabular}

* Obtained from a cross between SP1 and a pdel pde2 strain (DJ23-3C, provided by M. Wigler).

at $55^{\circ} \mathrm{C}$, cooled on ice and then transferred to a $30^{\circ} \mathrm{C}$ incubator. Growth was scored after $2 \mathrm{~d}$.

Incubation conditions and cAMP determinations. For cAMP measurements, cells were incubated at a density of $30 \mathrm{mg}$ (wet weight) $\mathrm{ml}^{-1}$ in a reciprocating water-bath at a temperature of $22^{\circ} \mathrm{C}, 30^{\circ} \mathrm{C}$ or $37^{\circ} \mathrm{C}$ as indicated in the figure legends. Incubation was carried out in $25 \mathrm{~mm}$ MES/KOH buffer ( $\mathrm{pH} \mathrm{6}$ ) for $10 \mathrm{~min}$ or $20 \mathrm{~min}$ (in the case of $37^{\circ} \mathrm{C}$ ) before addition of $100 \mathrm{~mm}$-glucose or $2 \mathrm{mM}$-2,4-dinitrophenol (DNP). For temperature shift experiments, cells were incubated in YPD, YPG or $25 \mathrm{~mm}-\mathrm{MES} / \mathrm{KOH}$ buffer $(\mathrm{pH} 6)$ for $1 \mathrm{~h}$ at $22{ }^{\circ} \mathrm{C}$ and then rapidly ( 1 $2 \mathrm{~min}$ ) shifted to $37^{\circ} \mathrm{C}$. cAMP was determined as described previously (Thevelein et al., 1987a). Glucose-induced cAMP responses were routinely followed for $3 \mathrm{~min}$, while DNP-induced responses were followed for $5 \mathrm{~min}$.

Cell transformation and DNA isolation. Transformation of E. coli cells was performed by standard methods (Maniatis et al., 1982). Transformation of yeast cells was done by the lithium acetate method (Ito et al., 1983). Yeast DNA was prepared essentially as described by Struhl et al. (1979). Plasmid DNA was isolated from E. coli (HB101) by the alkali lysis method (Maniatis et al., 1982).

In vivo ${ }^{31} P$-NMR spectroscopy. High-resolution ${ }^{31} \mathrm{P}-\mathrm{NMR}$ spectra of living cells were obtained on a Bruker AM-400 WB NMR spectrometer operating in the Fourier transform mode at $161.9 \mathrm{MHz}$. The spectra were accumulated at $25^{\circ} \mathrm{C}$ for $3 \min (312$ accumulations) after a $10 \mathrm{~min}$ pre-incubation period (for temperature equilibration). The polyphosphate peak was used for calibration ( -22.45 p.p.m.). Cells ( $4 \mathrm{~g}$ wet wt) were suspended in $25 \mathrm{~mm}-\mathrm{MES} / \mathrm{KOH}$ buffer $(\mathrm{pH} 6)$ (total volume $13 \mathrm{ml}$ ) in $20 \mathrm{~mm}$ NMR tubes. The cells were continuously bubbled with $\mathrm{O}_{2}$ (or $\mathrm{N}_{2}$ in some control experiments) using two glass capillaries. No substrate was added except in control experiments with mutants having high protein kinase activity (which are known to have low endogenous reserves). They were given $3 \%$ glycerol after the normal incubation period and after a second pre-incubation period of $10 \mathrm{~min}$, a new spectrum was accumulated.
Preparation of crude extracts and enzyme assays. Crude enzyme extracts for measurement of invertase and trehalase activity were prepared as described previously (Thevelein \& Beullens, 1985). Invertase activity was assayed by the procedure of Goldstein \& Lampen (1975) as modified by Celenza \& Carlson (1984). Trehalase activity was determined as described before (Thevelein et al., 1983), and trehalose levels were determined by the anthrone method (Ashwell, 1957). Total protein content was determined by the Lowry method.

Reproducibility of results. All experiments were repeated at least twice with consistent results. Representative results are shown.

\section{Results and Discussion}

\section{Stimulation of cAMP synthesis by glucose and by intracellular acidification}

Addition of $100 \mathrm{~mm}$-glucose or $2 \mathrm{~mm}$-dinitrophenol (DNP) to wild-type yeast cells grown on non-fermentable carbon sources triggers a rapid increase in the cAMP level (Fig. 1). With glucose, the cAMP increase is always transient so that it takes the form of a cAMP signal. A yeast strain with a disrupted $C D C 25$ gene in which viability was restored by a multicopy plasmid carrying the $T P K 1$ gene has a very low cAMP level (Broek et al., 1987) and did not show a glucose- or DNP-induced cAMP increase (results not shown). To investigate whether the CDC25 protein truly acts as a component of the signalling pathway, or whether it is merely required 

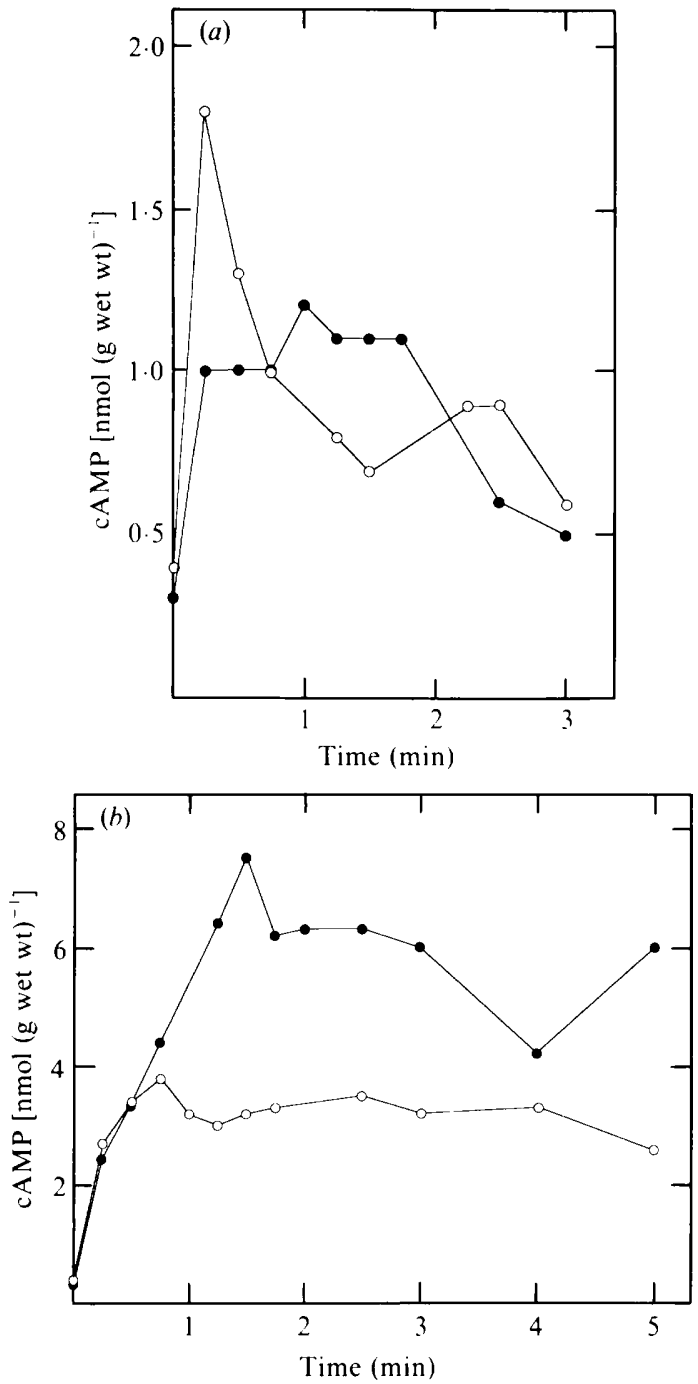

Fig. 1. Glucose-induced cAMP signal $(a)$ and DNP-induced cAMP increase $(b)$ at $22^{\circ} \mathrm{C}(O)$ and $37^{\circ} \mathrm{C}(\mathrm{O})$ in derepressed cells of the wild type strain A364A.

for basal cAMP synthesis, we measured the cAMP responses in strains lacking the $C D C 25$ gene but able to synthesize cAMP: $c d c 25:: H I S 3$ pRAS2 val19 and $c d c 25:: H I S 3 R A S 2^{\text {val19 }}$. The $R A S 2^{\text {val19 }}$ oncogene product does not depend on the CDC25 protein for its activity, and restores cAMP synthesis in strains lacking $C D C 25$ (Fig. 2). The cAMP level was higher in the $c d c 25:: H I S 3 \mathrm{p} R A S 2^{\text {val19 }}$ strain than in the $c d c 25:: H I S 3$ $R A S 2^{\text {val19 }}$ strain, probably owing to the higher copy number of $R A S 2^{\text {val } 19}$ in the former strain, caused by the presence of the multicopy YEp vector. The $R A S 2^{\text {val19 }}$ oncogene product itself is unable to transmit the cAMP signal. The strains however still contain $R A S I$ (and also $R A S 2$ in the $c d c 25:: H I S 3 \mathrm{p} R A S 2^{\text {val19 }}$ strain), which is able to transmit the cAMP signal in the presence of $R A S 2^{\text {val19 }}$ (Mbonyi et al., 1988). Addition of glucose to

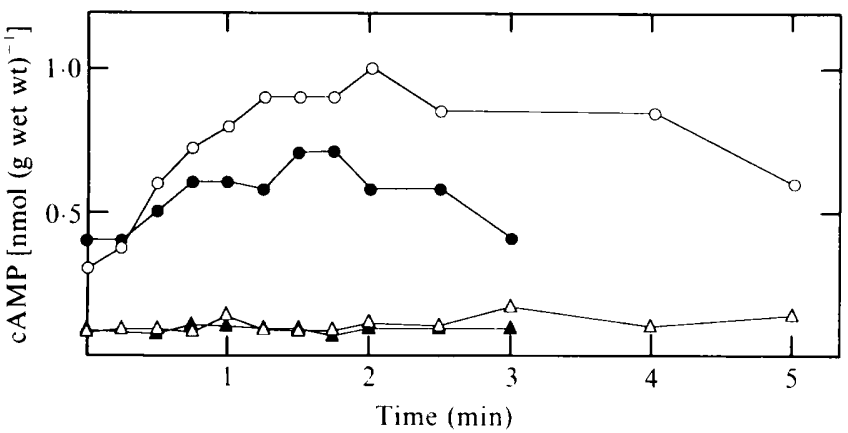

Fig. 2. cAMP level in derepressed cells of strain T139-5A-6A w/YEp $R A S 2^{\text {val19 }}\left(c d c 25 \mathrm{p} R A S 2^{\text {val19 }}\right)$ after addition of glucose (O) and DNP $(O)$, and in cells of strain JT1821 ( $\left.c d c 25 R A S 2^{\text {val19 }}\right)$ after addition of glucose $(\mathbf{\Delta})$ and DNP $(\triangle)$.

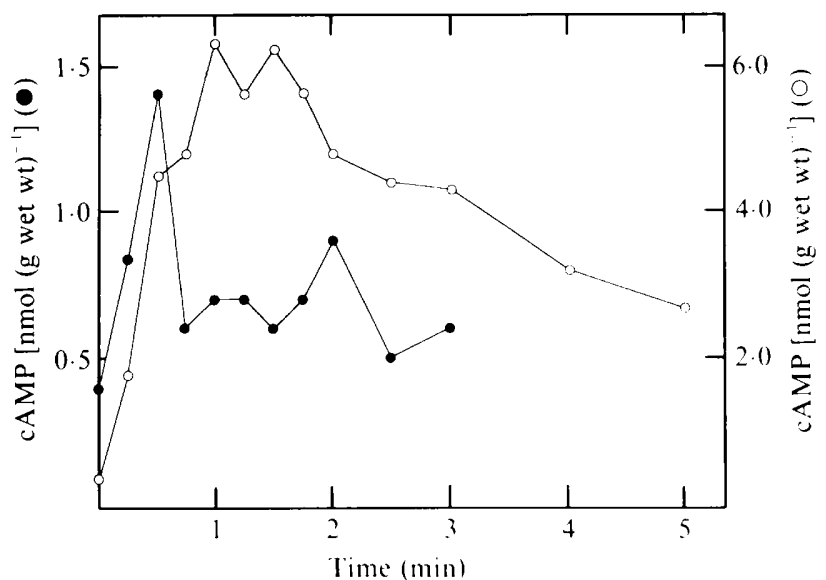

Fig. 3. Glucose-induced cAMP signal (, , ordinate on left scale) and DNP-induced cAMP increase (O, ordinate on right scale) in derepressed cells of the control strain JT4100 (wild-type strain SP1 with a plasmid containing the $R A S 2^{\text {val19 }}$ oncogene).

cells with a disrupted $C D C 25$ gene did not induce a typical cAMP signal. Neither did DNP cause a cAMP increase comparable to that in wild-type cells (Fig. 2). In the strain containing $\mathrm{p} R A S 2^{\mathrm{val} 19}$ some residual effect on the cAMP level was observed, the reason for which is not known. Control experiments with wild-type cells containing the $R A S 2^{\text {val19 }}$ oncogene in the genome (Mbonyi et al., 1988) or on a plasmid (Fig. 3) showed that the latter is not responsible, e.g. through increased feedbackinhibition (Nikawa et al., 1987; Mbonyi et al., 1990), for the absence of the cAMP responses.

Disruption of both $R A S$ genes in yeast is lethal, except for instance in strains lacking both the low-affinity (PDEl-encoded) and the high-affinity (PDE2-encoded) phosphodiesterases. In these strains, the basal cAMP level is also restored (Nikawa et al., 1987). In this paper we show that lethality due to $C D C 25$ disruption can be rescued by disruption of the gene encoding high-affinity 
phosphodiesterase. Comparison of the glucose- and DNP-induced cAMP increases in the $c d c 25$ pde 2 strain, in which the basal cAMP level is also restored, and the control strain $C D C 25$ pde 2 confirmed the importance of $\mathrm{CDC} 25$ for induction of the cAMP responses (results not shown). These results show that the CDC25 protein is required for transmission of the glucose-induced cAMP signal. Since the DNP effect also largely disappears when CDC25 is inactivated, intracellular acidification apparently activates the signal transmission pathway at the CDC25 protein or at some point upstream of CDC25. This point, however, must be located downstream of glucose phosphorylation, since yeast mutants lacking sugar kinase activity are only deficient in the glucoseinduced cAMP signal, and not in the DNP-induced cAMP increase (Beullens et al., 1988).

It has been suggested that the CDC 25 protein is a specific stimulator of GDP/GTP exchange on the RAS proteins (Broek et al., 1987; Camonis et al., 1986; Daniel, 1986; Daniel et al., 1987; Marshall et al., 1987). Addition of fermentable sugar to derepressed yeast cells probably activates the $\mathrm{CDC} 25$ protein, in turn causing a sudden stimulation of GDP/GTP exchange on the RAS proteins. This activates adenyl cyclase, which increases the cAMP level. The rapid decrease after the initial increase might be caused by feedback inhibition by cAMP-dependent protein kinase on one of the components of the signal transmission pathway (Nikawa et al., 1987; Mbonyi et al., 1990).

cAMP levels in the temperature-sensitive mutants cdc25-1 and $c d c 25-5$

Complementation experiments and analysis of the progeny of a cross of the $c d c 25-1$ and $c d c 25-5$ containing . strains confirmed that the two genes truly represent alleles (results not shown). The temperature-sensitive mutant $c d c 25-5$ showed a glucose- and DNP-induced cAMP increase at the permissive but not at the restrictive temperature $\left(37^{\circ} \mathrm{C}\right)$ (Fig. $\left.4 a\right)$. The absence of DNP effect at the restrictive temperature was not due to absence of intracellular acidification as measured by in vivo NMR (results not shown). In contrast, the $c d c 25-1$ mutant showed normal cAMP increases at both the permissive $\left(22^{\circ} \mathrm{C}\right)$ and the restrictive temperature $\left(37^{\circ} \mathrm{C}\right)$ (Fig. $\left.4 b\right)$. In agreement with the results obtained by Camonis et al. (1986) we found that the cellular cAMP content in $c d c 25-5$ mutants dropped precipitously when the cells were shifted to $37^{\circ} \mathrm{C}$. This was observed both in MES buffer and in rich medium containing either a fermentable or a non-fermentable carbon source (Fig. 5). As opposed to $c d c 25$-5-bearing cells, the cAMP level in the $c d c 25-1$ mutant did not drop, or even increased, when the cells were shifted to the restrictive temperature
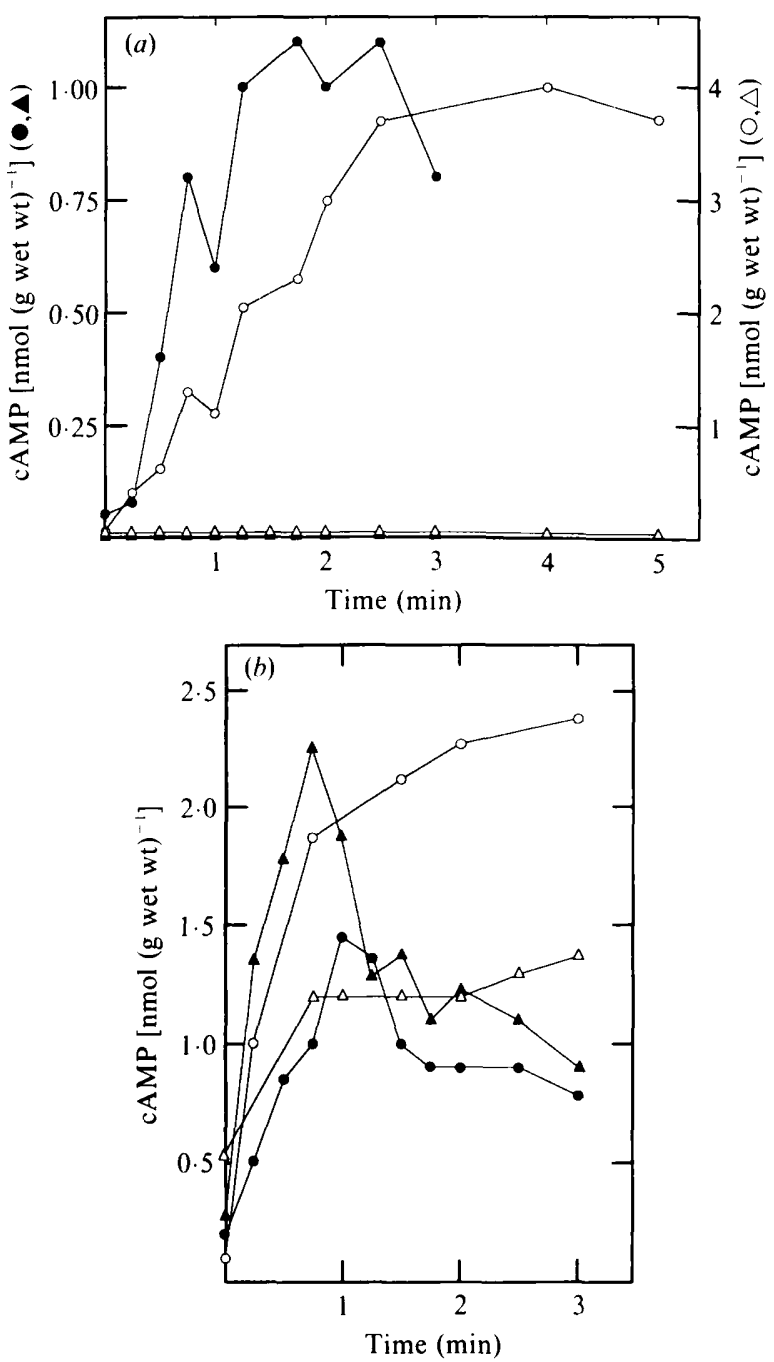

Fig. 4. cAMP level in the temperature-sensitive strains OL86 (cdc25-5) (a) and t.s.321 (cdc25-1) (b) after addition of glucose (filled symbols) and DNP (open symbols) at the permissive temperature of $22^{\circ} \mathrm{C}$ (circles) and at the restrictive temperature of $37^{\circ} \mathrm{C}$ (triangles).

$\left(37^{\circ} \mathrm{C}\right)$ (Fig. 5). This is in agreement with results obtained previously by Martegani et al. (1986b) and Portillo \& Mazon (1986). An increased cAMP level upon shift to high temperature is generally observed in wildtype strains (unpublished results). The experiments with $c d c 25-1$ and $c d c 25-5$ were carried out under exactly the same experimental conditions. Hence, our data confirm the discrepancy between the previous results obtained independently by different groups with the $c d c 25-1$ and $c d c 25-5$ mutants. It cannot be excluded however that the different genetic background in the strains also plays a role, as suggested by recent work from the group of Tatchell (Petitjean et al., 1990) in which the nucleotides modified in the $c d c 25-1$ and $c d c 25-5$ gene were identified, and in which it was claimed that both $c d c 25-1$ and $c d c 25$ 5 , when present in the same genetic background, resulted 


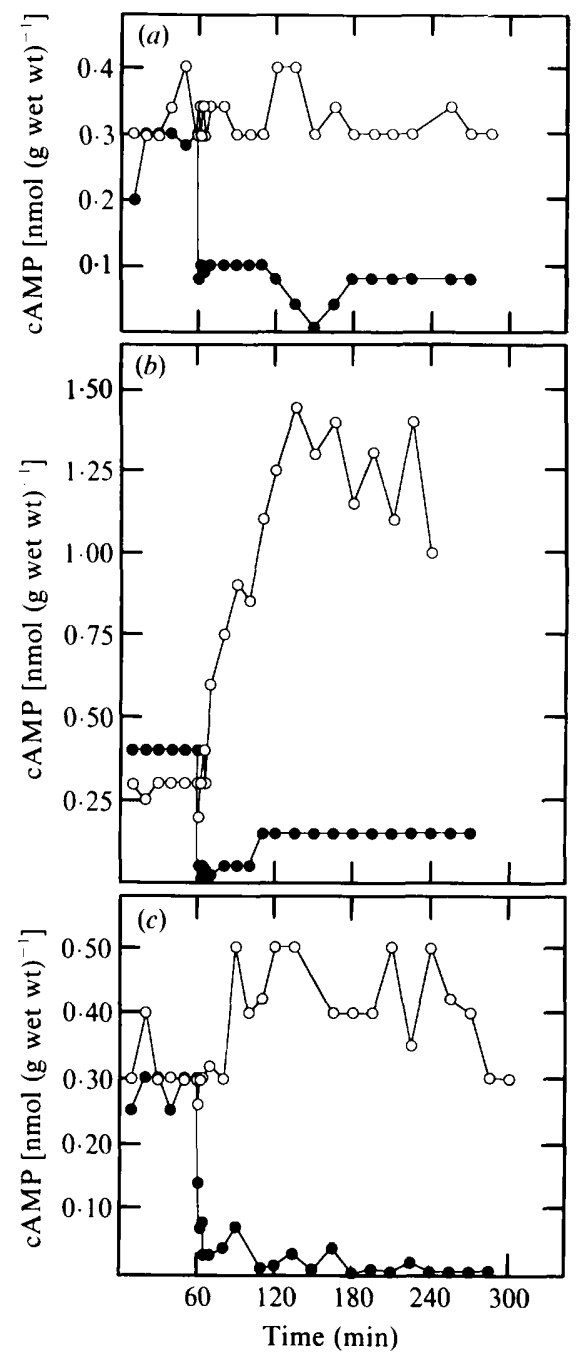

Fig. 5. cAMP level in the temperature-sensitive strains OL86 ( $c d c 25-5)$ (O) and t.s.321 (cdc25-I) (O) during incubation at the permissive temperature $\left(22^{\circ} \mathrm{C}\right)$ for $60 \mathrm{~min}$ and subsequent shift to the restrictive temperature $\left(37^{\circ} \mathrm{C}\right)$. The experiments were carried out in MES buffer $(a)$, YPD $(b)$ and YPG $(c)$.

in a drop of the cAMP level at the restrictive temperature. Unfortunately, the cAMP level in the original $c d c 25-1$ strain (t.s. 321) was not investigated. Our results with the original $c d c 25-1$ strain demonstrate that in yeast cells cAMP depletion is not required for arrest at the 'start' point of the cell cycle and for subsequent accumulation in the resting state $G_{0}$.

Is CDC25 the glucose-repressible component of the signal transmission pathway?

Glucose-repressed cells of wild-type strains do not show a glucose-induced cAMP signal, but they show a DNPinduced cAMP increase when they are provided with an

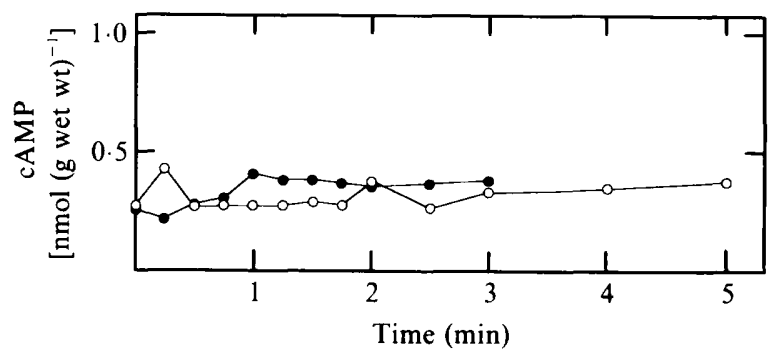

Fig. 6. cAMP level after addition at the permissive temperature $\left(22^{\circ} \mathrm{C}\right)$ of glucose (O) and DNP $(O)$ to glucose-repressed cells of strain OL86 (cdc25-5).

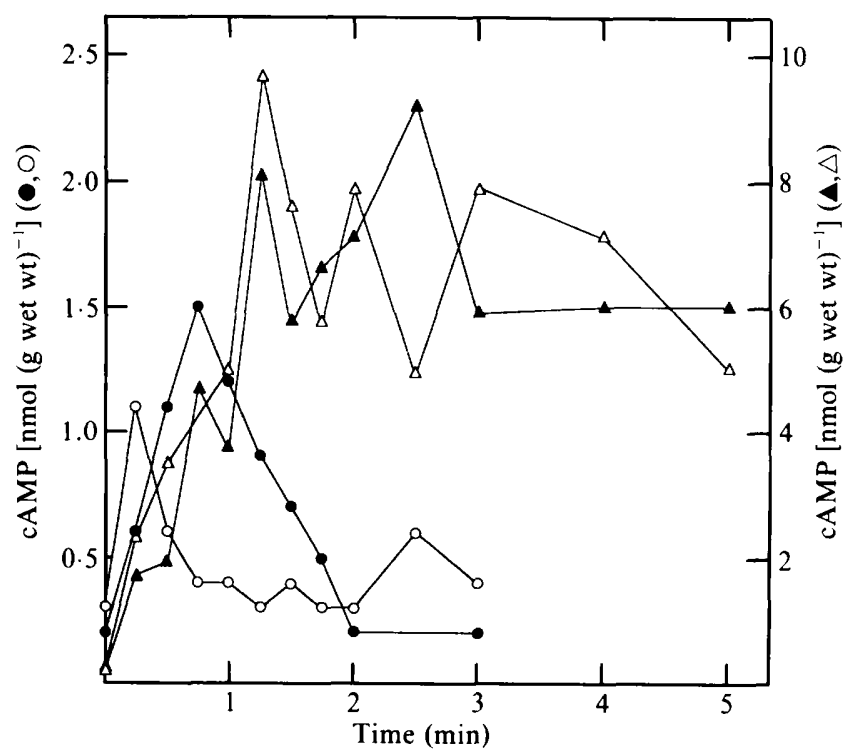

Fig. 7. Glucose-induced cAMP signal at $22^{\circ} \mathrm{C}(0)$ and $37^{\circ} \mathrm{C}(\mathrm{O})$ and DNP-induced cAMP increase at $22^{\circ} \mathrm{C}(\Delta)$ and $37^{\circ} \mathrm{C}(\triangle)$ in cells of strain OL97-1-11 B pL25 (cdc25-5 pCDC25) grown in YPD (at $37^{\circ} \mathrm{C}$ ) and harvested in exponential phase.

adequate ATP level (Beullens et al., 1988; Argüelles et $a l .$, 1990). Glucose-repressed cells have a very low ATP level when suspended in buffer (Thevelein et al., 1987b). The absence of both cAMP responses was observed with glucose-repressed cells of the $c d c 25-5$ strain (OL86) incubated at the permissive temperature in buffer (Fig. 6). However, exponential-phase glucose-grown cells of the $c d c 25-5$ mutant, containing a multi-copy plasmid with the $C D C 25$ gene, clearly showed a glucose- and DNP-induced cAMP increase (Fig. 7). This could indicate that the $\mathrm{CDC} 25$ protein is the putative glucoserepressible component of the signalling pathway. To check whether the cells with overexpression of CDC25 were still repressed we measured invertase activity and the level of mitochondrial respiration. For the latter, we investigated, by in vivo ${ }^{31} \mathrm{P}-\mathrm{NMR}$, the ATP level and the intracellular $\mathrm{pH}$ in cells suspended in MES buffer and 
Table 2. Invertase activity of cells grown in YPD and harvested in exponential phase or grown in YPD until the glucose in the medium was exhausted ('derepressed cells')

\begin{tabular}{llcc}
\hline \hline & & \multicolumn{2}{c}{ Invertase activity $\left[\mathrm{nmol} \mathrm{\textrm {min } ^ { - 1 } ( \mathrm { mg } \mathrm { protein } ) ^ { - 1 } ]}\right.$} \\
\cline { 3 - 4 } Strain & $\begin{array}{c}\text { Relevant } \\
\text { genotype }\end{array}$ & $\begin{array}{c}\text { Exponential-phase } \\
\text { glucose-grown cells }\end{array}$ & $\begin{array}{c}\text { Derepressed } \\
\text { cells }\end{array}$ \\
\hline A364A & Wild-type & $25 \cdot 8$ & 528 \\
t.s.321 & $c d c 25-1$ & 45.9 & 1007 \\
OL86 & $c d c 25-5$ & 12.0 & $169 \cdot 5$ \\
OL97-1-11B pL25 & $c d c 25-5$ pCDC25 & 1151 & 1755 \\
\hline \hline
\end{tabular}

bubbled with oxygen (den Hollander et al., 1981; Thevelein et al., 1987b). Unexpectedly, overexpression of CDC25 abolished glucose repression as measured by the level of invertase activity (Table 2) and mitochondrial respiration (Fig. 8, Table 3). To solve this problem we made use of the catl mutation, which prevents derepression. Because they lack respiration, cat $1 \mathrm{mu}-$ tants are unable to grow on non-fermentable carbon sources. The mutation, however, does not affect derepression of invertase activity, because of the presence

(a)

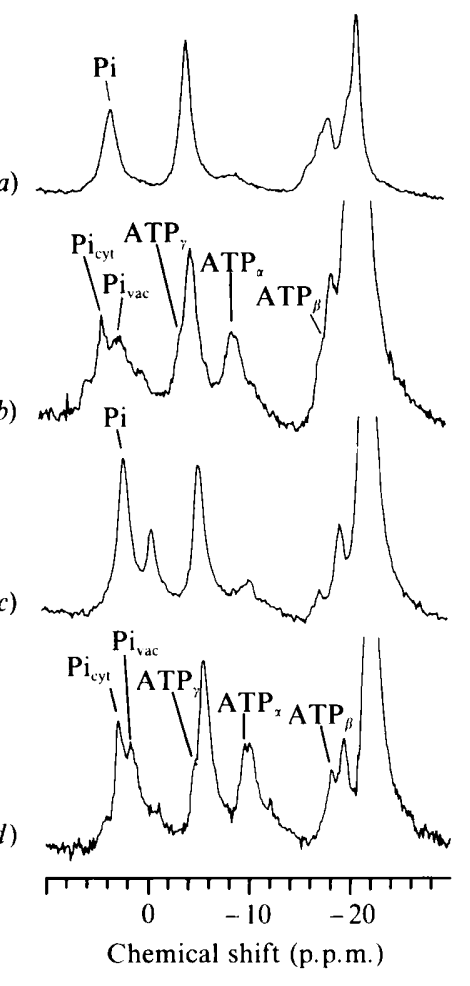

Fig. 8. ${ }^{31} \mathrm{P}-\mathrm{NMR}$ spectra of yeast cells grown on YPD and harvested in exponential phase. The cells were incubated in MES buffer at $25^{\circ} \mathrm{C}$ and bubbled with oxygen. (a) OL86 (cdc25-5); (b) OL97-1-11B pL25 (cdc25-5 pCDC25); (c) JT4200 (cat1 pCDC25); (d) JT4300 (CATI $\mathrm{p} C D C 25)$. $\mathrm{Pi}$, intracellular phosphate peak; $\mathrm{Pi}_{\mathrm{cy}}$, cytoplasmic phosphate peak; $\mathrm{Pi}_{\text {vac }}$, vacuolar phosphate peak. $\mathrm{ATP}_{\alpha}, \mathrm{ATP}_{\beta}, \mathrm{ATP}_{\gamma} ; \alpha, \beta, \gamma$ phosphate groups of ATP. of a suppressor allele in the genetic background of the cat 1 strains (Entian, 1986; Entian \& Zimmerman, 1982; Zimmerman et al., 1977). As is also the case for the cat3 derepression mutant, catl cells do not show a glucoseinduced cAMP signal, nor do they show a DNP-induced cAMP increase when simply suspended in buffer (Argüelles et al., 1990). Transformation of a catl strain with the $\mathrm{pCDC} 25$ plasmid did not result in suppression of the deficiency in derepression of mitochondrial functions, and the transformed strain did not grow on nonfermentable carbon sources (results not shown). Investigation of glucose-grown cells of the cat $1 \mathrm{p} C D C 25$ strain by in vivo ${ }^{31} \mathrm{P}-\mathrm{NMR}$ showed that the cells were repressed, compared to cells of a $C A T 1 \mathrm{pCDC25}$ strain (Fig. 8,

Table 3. ATP level and intracellular $p H$, as measured by in vivo ${ }^{31} P-N M R$, in glucose-grown cells of strains with and without overexpression of CDC25

The cells were grown on YPD, harvested in exponential phase, suspended in MES buffer and bubbled with oxygen

\begin{tabular}{lllc}
\hline \hline Strain & Relevant genotype & ATP level* & $\begin{array}{c}\text { Intracellular } \\
\mathrm{pH} \dagger\end{array}$ \\
\hline OL86 $\left(22^{\circ} \mathrm{C}\right)$ & $c d c 25-5$ & Low & $6 \cdot 0$ \\
OL97-1-11 B pL25 & $c d c 25-5 \mathrm{pCDC25}$ & High & $7 \cdot 1$ \\
SP1 & $C D C 25$ & Low & $6 \cdot 1$ \\
JT4101 & $C D C 25 \mathrm{p} C D C 25$ & Intermediate & $6 \cdot 9$ \\
JT2000 & cat1 & Low & $6 \cdot 5$ \\
JT4200 & $c a t 1 \mathrm{p} C D C 25$ & Low & $6 \cdot 4$ \\
JT2010 & $C A T 1$ & Low & $6 \cdot 0$ \\
JT4300 & $C A T 1$ pCDC25 & High & $7 \cdot 1$ \\
\hline \hline
\end{tabular}

* In vivo NMR is not well suited for accurate measurement of cellular ATP levels. The difference between the ATP level in repressed cells and derepressed cells however is very clear (Fig. 8). A high ATP level under these experimental conditions is typical for derepressed cells. Because they have respiration they can synthesize ATP from internal carbon sources. Repressed cells can only use fermentation to synthesize ATP and since there is no glucose in the medium, the ATP level of repressed cells under these conditions is low.

† A low intracellular pH under these experimental conditions is typical for repressed cells beacause they lack ATP. Derepressed cells have a high intracellular $\mathrm{pH}$ because they can use their ATP to pump protons out of the cell. 


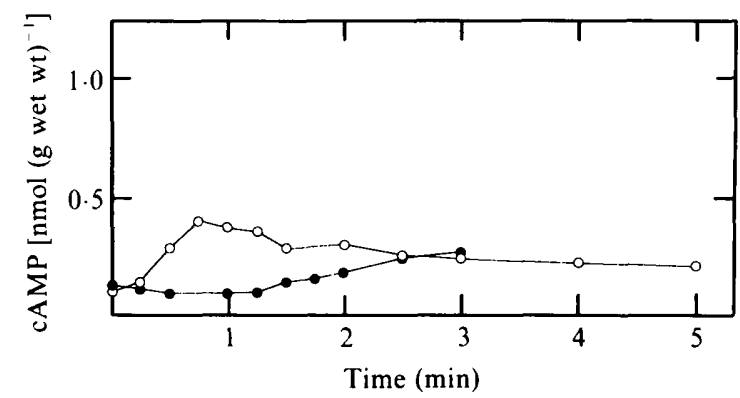

Fig. 9. cAMP level after addition of glucose (O) and DNP (O) to glucose-repressed cells of strain JT4200 (catl pCDC25).

Table 3). Addition of glucose or DNP to cells of the cat 1 strain with overexpression of CDC25 failed to produce cAMP increases (Fig. 9). This indicates that CDC25 is not the putative glucose-repressible component of the signal transmission pathway leading to activation of adenyl cyclase. Control experiments showed that overexpression of CDC25 in other wild-type strains (JT2010 and SP1) also resulted in the abolition of glucose repression, and the presence of glucose- and DNPinduced responses (results not shown).

Two possible explanations can be given for the abolition of glucose repression by overexpression of CDC25. Either overexpression of CDC25 interferes with the activity of a component needed for normal glucose repression (i.e. glucose repression is disrupted) or CDC25 protein acts as a positive stimulator of derepression, with the consequence that overexpression of CDC25 causes derepression under conditions in which the cells are normally repressed. In this respect, it might be recalled that in wild-type cells the level of $C D C 25$ transcript is very low (Camonis et al., 1986; Martegani et al., 1986a). Strain OL86 (cdc25-5) had a relatively low invertase activity under derepressed conditions (Table 2 ), which is apparently due to the genetic background. As can be seen in Table 2, overexpression of CDC25 resulted in a much higher activity of invertase. This result suggests that $\mathrm{CDC} 25$ protein acts as a positive stimulator of derepression and not as an artificial inhibitor of glucose repression.

It is important to note that the glucose-activation pathway of the CDC25/RAS/adenyl cyclase complex is dispensable for basal cAMP synthesis. The latter is shown by the fact that the glucose-activation pathway is glucose-repressible, and that it depends on sugar kinase activity, since mutants without sugar kinase activity display a normal basal cAMP level (Beullens et al., 1988). Fermentable sugar might be considered an unusual trigger for a signal transmission pathway. In mammalian cells the best-understood signal transmission pathways are triggered by hormones and growth factors (Berridge, 1987: Gilman, 1987). In large multicellular organisms, hormones and growth factors are prime regulators of cell metabolism and proliferation. In micro-organisms, on the other hand, nutrients are the prime regulators of metabolism and proliferation. In yeast, in particular, fermentable sugar is the preferred carbon substrate, and it should not surprise us if yeast cells contain a sophisticated system for sensing and responding to the level of fermentable sugar in their environment. In addition to fermentable sugar, however, there may exist other pathways for specific activation of the CDC25/RAS/adenyl cyclase complex. It must also be stressed that glucose-induced activation of cAMP synthesis through the RAS pathway is dispensable for growth on glucose and hence for progression over the 'start' point of the yeast cell cycle. The glucose-activation pathway is shut off as soon as the cells are repressed, and therefore it functions only during the transition from the derepressed state to the repressed state. If glucose acts as a stimulator of progression over the 'start' point of the yeast cell cycle, it is not through the glucose-activation pathway of the CDC25/RAS/adenyl cyclase complex.

We wish to thank M. Wigler (Cold Spring Harbor Laboratory), M. Jacquet (Orsay, France), K.-D. Entian (Tübingen, FRG) and the Yeast Genetic Stock Center (Berkeley) for provision of yeast mutants. We are also grateful to Dr M. Jacquet and Dr E. Boy-Marcotte for many stimulating discussions. This work was supported by grants from the KU Leuven Research Council, the Belgian National Fund for Scientific Research (FGWO, 'Kom op tegen Kanker'), the National Bank of Belgium, the Belgian National Lottery and the North Atlantic Treaty Organization (grant 5-2-05/RG86/174).

\section{References}

Argüelles, J.-C., Mbonyi, K., Van Aelst, L., Vanhalewyn, M., Jans, A. W. H. \& Thevelein, J. M. (1990). Absence of glucoseinduced cAMP signalling in the Saccharomyces cerevisiae mutants cat 1 and cat 3 which are deficient in derepression of glucoserepressible proteins. Archives of Microbiology 154, 199-205.

Ashwell, G. (1957). Colorimetric analysis of sugars. Methods in Enzymology 3, 73-105.

BERRIDGE, M. J. (1987). Inositol trisphosphate and diacylglycerol: two interacting second messengers. Annual Review of Biochemistry 56, 159-193.

Beullens, M. \& Thevelein, J. M. (1990). Investigation of transportassociated phosphorylation of sugar in yeast mutants (snf 3 ) lacking high-affinity glucose transport and in a mutant $(f d p l)$ showing deficient regulation of initial sugar metabolism. Current Microbiology 21, 39-46.

Beullens, M., Mbonyi, K., Geerts, L., Gladines, D., Detremerie, K., Jans, A. W. H. \& Thevelein, J. M. (1988). Studies on the mechanism of the glucose-induced cAMP-signal in glycolysis- and glucose repression-mutants of the yeast Saccharomyces cerevisiae. European Journal of Biochemistry 172, 227-231.

Boutelet, F., Petitjean, A. \& Hilger, F. (1985). Yeast $c d c 35$ mutants are defective in adenylate cyclase and are allelic with cyrl mutants while $C A S I$, a new gene, is involved in the regulation of adenyl cyclase. EMBO Journal 4, 2635-2641.

Broek, D., Toda, T., Michaeli, T., Levin, L., Birchmeier, C., Zoller, M., PoWers, S. \& Wigler, M. (1987). The Saccharomyces cerevisiae $C D C 25$ gene product regulates the RAS/adenylate cyclase pathway. Cell 48, 789-799. 
Camonis, J. H., Kalékine, M., Gondré, B., Garreau, H., BoyMARCOTTE, E. \& JACQUET, M. (1986). Characterization, cloning and sequence analysis of the $C D C 25$ gene which controls the cyclic AMP level of Saccharomyces cerevisiae. EMBO Journal 5, 375-380.

Caspani, G., Tortora, P., Hanozet, G. M. \& Guerritore, A. (1985). Glucose-stimulated cAMP increase may be mediated by intracellular acidification in Saccharomyces cerevisiae. FEBS Letters 186, 7579.

Casperson, G. F., Walker, N. \& Bourne, H. R. (1985). Isolation of the gene encoding adenylate cyclase in Saccharomyces cerevisiae. Proceedings of the National Academy of Sciences of the United States of America 82, 5060-5063.

Celenza, J. L. \& CARlson, M. (1984). Cloning and genetic mapping of $S N F 1$, a gene required for expression of glucose-repressible genes in Saccharomyces cerevisiae. Molecular and Cellular Biology 4, 49-53.

DANIEL, J. (1986). The CDC25 'start' gene of Saccharomyces cerevisiae: sequencing of the active C-terminal fragment and regional homologies with rhodopsin and cytochrome P450. Current Genetics 10, 879-885.

Daniel, J., Becker, J. M., Enari, E. \& Levitzki, A. (1987). The activation of adenylate cyclase by guanyl nucleotides in Saccharomyces cerevisiae is controlled by the $C D C 25$ start gene product. Molecular and Cellular Biology 7, 3857-3861.

Defeo-Jones, D., Scolnick, E. M., KolleR, R. \& DhaR, R. (1983). ras-Related gene sequences identified and isolated from Saccharomyces cerevisiae. Nature, London 306, 707-709.

Defeo-Jones, D., Tatchell, K., Robinson, L. C., Sigal, I. S., Vass, W. C., Lowy, D. R. \& SColNick, E. M. (1965). Mammalian and yeast ras gene products: biological function in their heterologous systems. Science 228, 179-184.

Dhar, R., Nieto, A., Koller, R., Defeo-Jones, D. \& Scolnick, E. (1984). Nucleotide sequence of two $\mathrm{ras}^{\mathrm{H}}$ related-genes isolated from the yeast Saccharomyces cerevisiae. Nucleic Acids Research 12, 3611-3618.

EnTiAN, K.-D. (1986). Glucose repression: a complex regulatory system in yeast. Microbiological Sciences 3, 366-371.

ENTIAN, K.-D. \& ZimmermanN, F. K. (1982). New genes involved in carbon catabolite repression and derepression in the yeast Saccharomyces cerevisiae. Journal of Bacteriology 151, 1123-1128.

GiLmAN, A. G. (1987). G proteins: transducers of receptor-generated signals. Annual Review of Biochemistry 56, 615-649.

GoldsteIN, A. \& LAMPEN, J. O. (1975). $\beta$-D-Fructofuranoside fructohydrolase from yeast. Methods in Enzymology 42C, 504-511

Den Hollander, J. A., Ugurbil, K., Brown, T. R. \& Shulman, R. G. (1981). ${ }^{31}$ P-NMR studies of the effect of oxygen upon glycolysis in yeast. Biochemistry 20, 5871-5880.

Ito, H., Fukuda, Y., Murata, K. \& Kimura, A. (1983). Transformation of intact yeast cells treated with alkali cations. Journal of Bacteriology 153, 163-168.

Kataoka, T., Powers, S., Cameron, S., Fasano, O., Goldfarb, M., BROACH, J. \& WIGLER, M. (1985). Functional homology of mammalian and yeast $R A S$ genes. Cell 40, 19-26.

Kataoka, T., Powers, S., McGill, C., Fasano, O., Strathern, J., BROACH, J. \& WIGLER, M. (1984). Genetic analysis of yeast RASI and $R A S 2$ genes. Cell 37, 437-445.

Maniatis, T., Fritsch, E. F. \& Sambrook, J. (1982). Molecular Cloning; a Laboratory Manual. Cold Spring Harbor, NY: Cold Spring Harbor Laboratory.

MaRShall, M. S., GibBS. J. B., Scolnick, E. M. \& Sigal, I. S. (1987). Regulatory function of the Saccharomyces cerevisiae RAS Cterminus. Molecular and Cellular Biology 7, 2309-2315.

Martegani, E., Baroni, M., Frascotti, G. \& Alberghina, L. $(1986 a)$. Molecular cloning and transcriptional analysis of the start gene CDC25 of Saccharomyces cerevisiae. EMBO Journal 5, 2363-2369.

MARTEGANI, E., BARONI, M. \& WANONI, M. (1986b). Interaction of cAMP with the $C D C 25$-mediated step in the cell cycle of budding yeast. Experimental Cell Research 162, 544-548.

Mbonyi, K. \& TheVelein, J. M. (1988). The high-affinity glucose
Mbonyi, K., Beullens, M., Detremerie, K., Geerts, L. \& uptake system is not required for induction of the RAS-mediated cAMP signal by glucose in cells of the yeast Saccharomyces cerevisiae. Biochimica et Biophysica Acta 971, 223-226.

TheVeLerN, J. M. (1988). Requirement of one functional $R A S$ gene and inability of an oncogenic ras variant to mediate the glucoseinduced cyclic AMP signal in the yeast Saccharomyces cerevisiae. Molecular and Cellular Biology 8, 3051-3057.

Mbonyi, K., Van Aelst, L., Argüelles, J. C., Jans, A. W. H. \& THEvelein, J. M. (1990). Glucose-induced hyperaccumulation of cyclic AMP and defective glucose repression in yeast strains with reduced activity of cyclic AMP-dependent protein kinase. Molecular and Cellular Biology 10, 4518-4523.

MUNDER, T. \& KÜNTZEL, H. (1989). Glucose-induced cAMP signalling in Saccharomyces cerevisiae is mediated by the CDC25 protein. FEBS Letters 242, 341-345.

Nikawa, J., Cameron, S., Toda, T., Ferguson, K. M. \& Wigler, M. (1987). Rigorous feedback control of cAMP levels in Saccharomyces cerevisiae. Genes \& Development 1, 931-937.

Petitjean, A., Hilger, F. \& Tatchell, K. (1990). Comparison of thermosensitive alleles of the CDC25 gene involved in the cAMP metabolism of Saccharomyces cerevisiae. Genetics 124, 797-806.

Portillo, F. \& MAZON, M. J. (1986). The Saccharomyces cerevisiae start mutant carrying the $c d c 25$ mutation is defective in activation of plasma membrane ATPase by glucose. Journal of Bacteriology 168, 1254-1257.

Purwin, C., Nicolay, K., Scheffers, W. A. \& Holzer, H. (1986). Mechanism of control of adenylate cyclase activity in yeast by fermentable sugars and carbonyl cyanide $m$-chlorophenylhydrazone. Journal of Biological Chemistry 261, 8744-8749.

Robinson, L. C., Gibbs, J. B., Marshall, M. S., Sigal, I. S. \& TATCHELL, K. (1987). cdc25: a component of the Ras-adenylate cyclase pathway in Saccharomyces cerevisiae. Science 235, 1218-1221.

Sherman, F., Fink, G. R. \& Hicks, J. B. (1985). Methods in Yeast Genetics. Cold Spring Harbor, NY: Cold Spring Harbor Laboratory.

StrUhl, K., StinchComb, D. T., Scherer, S. \& Davis, R. W. (1979). High-frequency transformation of yeast: autonomous replication of hybrid DNA. Proceedings of the National Academy of Sciences of the United States of America 76, 1035-1039.

THEvelein, J. M. (1988). Regulation of trehalase activity by phosphorylation-dephosphorylation during developmental transitions in fungi. Experimental Mycology 12, 1-12.

Thevelein, J. M. \& Beullens, M. (1985). Cyclic AMP and the stimulation of trehalase activity in the yeast Saccharomyces cerevisiae by carbon sources, nitrogen sources and inhibitors of protein synthesis. Journal of General Microbiology 131, 3199-3209.

Thevelein, J. M., Van Laere, A. J., Beullens, M., Van Assche, J. A. \& CARLIER, A. R. (1983). Glucose-induced trehalase activation and trehalose mobilization during early germination of Phycomyces blakesleeanus spores. Journal of General Microbiology 129, 719-726.

Thevelein, J. M., Beullens, M., Honshoven, F., Hoebeeck, G., Detremerie, K., Den Hollander, J. A. \& JANS, A. W. H. (1987a). Regulation of the cAMP level in the yeast Saccharomyces cerevisiae: intracellular $\mathrm{pH}$ and the effect of membrane depolarizing compounds. Journal of General Microbiology 133, 2191-2196.

Thevelein, J. M., Beullens, M., Honshoven, F., Hoebeeck, G., Detremerie, K., Griewel, B., Den Hollander, J. A. \& Jans, A. W. H. $(1987 b)$. Regulation of the cAMP level in the yeast Saccharomyces cerevisiae: the glucose-induced cAMP signal is not mediated by a transient drop in the intracellular $\mathrm{pH}$. Journal of General Microbiology 133, 2197-2205.

Toda, T., Uno, I., Ishikawa, T., Powers, S., Kataoka, T., Broek, D., Cameron, S., Broach, J., Matsumoto, K. \& Wigler, M. (1985). In yeast, $R A S$ proteins are controlling elements of adenylate cyclase. Cell 40, 27-36.

Zimmerman, F. K., Kaufmann, I., Rasenberger, H. \& HauBManN, P. (1977). Genetics of carbon catabolite repression in Saccharomyces cerevisiae: genes involved in the derepression process. Molecular and General Genetics 151, 95-103. 